\title{
Study on the Cross-Cultural Management of Chinese Enterprises under "The Belt and Road "Initiative
}

\author{
Minna $\mathrm{Wu} *$ \\ The College of Arts and Sciences Yunnan \\ Normal University \\ Kunming, China \\ 823605805@qq.com
}

\author{
Chongyou Ruan \\ The College of Arts and Sciences Yunnan \\ Normal University \\ Kunming, China
}

\begin{abstract}
At present, "The Belt and Road" initiative creates a good opportunity for the development of the enterprises "going out". But, the cultural conflict between two countries in transnational operation is a serious problem that Chinese enterprises will inevitably face in the process of development. In the future, China's related industries and enterprises will go abroad and move towards the international market. If Chinese enterprises want to go out and go for a longer term, the problem of cross-cultural management must be solved. Therefore, in this paper, under "The Belt and Road" background, the cultural differences between China and the countries along the Belt and Road is analyzed, and a cross culture management strategy of Chinese enterprises is put forward.
\end{abstract}

Keywords-“The Belt and Road" Initiative; Chinese enterprises; cross-cultural management

\section{INTRODUCTION}

With the development of economic globalization, in September 2013, Chinese President Xi Jinping proposed the great initiative of many countries to build "the Silk Road Economic Belt" and "the 21st- Century Maritime Silk Road", which is referred to as "The Belt and Road." Unprecedented opportunities for Chinese enterprises to go out are provided. However, in the process of international operation of the enterprise, greater cultural differences and cultural conflicts are bound to be faced. Regional differences exist between Chinese enterprises and the areas where they operate. As a result, there are more regional differences that the development of Chinese enterprises needs to face. Correct cross-cultural concepts should be established by Chinese enterprises. The cultural differences should be treated objectively, and a correct understanding of the national culture of the target market should be formed. Only in this way can Chinese enterprises go further.

\section{AN OVERVIEW OF “THE BELT AND ROAD" INITIATIVE}

"The Belt and Road" is the abbreviation for "Silk Road Economic Belt" in twenty-first Century and "maritime Silk Road". In September and October, 2013, Chinese President Xi Jinping put forward the cooperation proposal on building
"The New Silk Road Economic Belt" and "the 21st Century Maritime Silk Road". It will fully rely on the existing dual multilateral mechanisms between China and the relevant countries, with the help of existing and effective regional cooperation platform. "The Belt and Road" aims to borrow the historical symbols of the ancient Silk Road, hold high the banner of peaceful development, actively develop economic partnership with the countries along the route, and create a political mutual trust, economic integration, cultural inclusion interest community, destiny community and responsibility community. "The Belt" is an economic belt consists of three routes, which includes: from China, via central Asia and Russia, to Europe; from China, via the Western Asia and Persian Gulf, to the Mediterranean; from China, via Southeast Asia and South Asia, to India Ocean. "The Road" consists of two routes: first, from China's coastal ports, across the South China Sea, to the South Pacific; second, from China's coastal ports, across the South China Sea, through India ocean, to Europe. a total of 65 countries and regions including China are involved in "The Belt and Road".(See table I).

TABLE I. THE COUNTRIES ALONG THE BeLt AND RoAD

\begin{tabular}{|c|c|}
\hline plate & Major countries \\
\hline Central Asia & $\begin{array}{l}\text { Kazakhstan, Kyrgyzstan, Tajikistan, Uzbekistan and } \\
\text { Turkmenistan }\end{array}$ \\
\hline $\begin{array}{l}\text { Mongolia and } \\
\text { Russia }\end{array}$ & Mongolia, Russia \\
\hline Southeast Asia & $\begin{array}{l}\text { Vietnam, Laos, Kampuchea, Thailand, Malaysia, } \\
\text { Singapore, Indonesia, Brunei, Philippines, Burma, } \\
\text { East Timor }\end{array}$ \\
\hline South Asia & $\begin{array}{l}\text { India, Pakistan, Bangladesh, Afghanistan, Nepal, } \\
\text { Bhutan, Sri Lanka and Maldives. }\end{array}$ \\
\hline $\begin{array}{l}\text { The Middle East } \\
\text { (including Egypt }\end{array}$ & $\begin{array}{l}\text { Turkey, Iran, Syria, Iraq, the United Arab Emirates, } \\
\text { Saudi Arabia, Qatar, Bahrain, Kuwait, Lebanon, }\end{array}$ \\
\hline
\end{tabular}

*Corresponding author 


\begin{tabular}{|c|l|}
\hline $\begin{array}{c}\text { in West Asia and } \\
\text { Africa) }\end{array}$ & $\begin{array}{c}\text { Oman, Yemen, Jordan, Israel, Palestine, Armenia, } \\
\text { Georgia, Azerbaijan, Egypt. }\end{array}$ \\
\hline Central Europe & $\begin{array}{l}\text { Poland, Jack, Slovakia, Hungary, Slovenia, Croatia, } \\
\text { Croatia, Romania, Bulgaria, Serbia, Montenegro, } \\
\text { Macedonia, Bosnia, Bosnia, Bosnia and Herzegovina, } \\
\text { Albania, Estonia, Lithuania, Latvia, Ukraine, Belarus, } \\
\text { Moldova }\end{array}$ \\
\hline
\end{tabular}

\section{AN OVERVIEW OF CROSS CUlture MANAGEMENT}

Cross culture management is also called intercultural management, which, in the globalized operation, with a tolerant management approach to the culture of the country where the subsidiary is located, aims to overcome conflicts brought by other cultures under cross cultural conditions, and form a fruitful management process. That is to say, in the operation of multinational enterprises, this is a progress in which an inclusive and intercultural management of integrated management is completed facing the culture of different races, cultures of different regions and different stages of culture [2].

\section{CUltural DifFERENCE ANALYSIS BETWEEN CHINA AND THE COUNTRIES ALONG THE BELT AND ROAD}

Great opportunities are provided for Chinese enterprises to go out by "The Belt and Road Initiative". But "The Belt and Road" is along the way through Asia, Europe, Africa, where four great civilizations are located, and also Involves 65 countries, which are different in customs, religious beliefs and cultural traditions and with different values, customs and behaviors. Unprecedented challenges in the construction process of the countries along the route will be encountered by Chinese enterprises:

\section{A. Differences in Customs and Habits}

Custom refers to a kind of behavior pattern and the corresponding standard way that people follow in a certain area of existing culture through the selection and elimination of the past generation, and it will produce a very strong behavioral restriction to its social members. The typical way of thinking of a nation is the fundamental basis of all spiritual civilization. Therefore, the various customs and habits of the host country, including the way of life and the way of work of the host country must understand, respect and adapt to by the managers of transnational business enterprises [3].

\section{B. Religious Belief Differences}

Religion is also an important part of culture, which is a close combination of national consciousness and also a sensitive and complex cultural problem. Many cultural conflicts are caused by the differences of ideas between different religions. Most people in the world are influenced by different religious cultures, for example, the Arabia countries are influenced by Islam, and the oriental culture has been influenced by Buddhism and Confucianism for a long time [4]. As a result, enterprises are always confronted with the contradictions caused by the religious problems of their members in the transnational operation, so the degree of tolerance among the religions and the importance of religion in a society and in the mind of the employees need to be understood by the managers. Only by effectively avoiding the differences brought about by religious beliefs can enterprises achieve remarkable results in their transnational operations.

\section{Values Differences}

People living in different countries and different regions and touching different things formed different cultural atmosphere and different values. Firstly, take the collectivism and individualism, which is first put forward by the Holland management scientist Hofstede, as an example, a better understanding of the differences in values can be achieved. In short, individualism and collectivism refer to the relationship between individuals and groups in society. In a collectivist country, the members of the state should first consider the interests of the organization and other people, but not simply the individual interests [5]. Thus, the members of the state will produce spiritual obligations and loyalty to the organization, and will not betray the collective in the interests of the individual. But in an individualist country, each member needs only to take care of its own interests, without taking into account the interests of others, and the members of the state are also free to choose their own actions. Secondly, differences in values can also lead to differences in privacy values. In China, for example, there is no offense in asking for age among colleagues, but in an open western society, asking about the age of others, especially asking about the age of women, is an extremely impolite behavior. This is because Westerners think that age is a very private matter, and people should not be involved in the privacy of others in this respect.

\section{Cross-cultural Communication Barrier}

Cross-cultural communication refers to the communication behaviors between people from different cultural backgrounds. In today's society, intercultural communication is becoming more and more difficult. To a great extent, the cultural conflict is caused by different factors such as region, race, and life experience and so on. Therefore, a comprehensive understanding of different cultures is the basis of human behavior and interaction with others, and a prerequisite for better and more effective communication. In the process of transnational operation, different kinds of culture are often faced by Chinese enterprises. If a party always looks at the other side with its inherent and national stereotypes, there will often be deviations. Although the inherent cultural impression can reflect the cultural characteristics and help the enterprise to recognize the group in the culture more quickly, but if we just stay at the level of the surface of the known cultural impression and give up more opportunities for communication, more problems shall exist. Therefore, if there is a lack of mutual trust between groups, simply using power or acting ethnicity will lead to cultural conflict, which will also affect the normal operation of enterprises.

\section{THE COUNTERMEASURES OF CHINESE ENTERPRISES' Cross Culture MANAGMENT}

\section{A. Establishment of Human Resource Management System}

\section{Based on Cultural Differences}

Human resources are the primary resources of an 
enterprise and the core work of cross culture management is human resource management. It is necessary to build a human resource management system based on the background of cultural differences in the transnational operation of enterprises [6]. In the construction of human resources management system, first of all, we must establish and improve recruitment system. Aiming at employees with different cultural backgrounds, the recruitment system should be formulated in a targeted way, so that the employees in the recruitment process meet the requirements of the enterprise. Secondly, the system of enterprise culture training should be improved. By establishing a scientific training mechanism of corporate culture, employees can identify the corporate culture and eliminate the problems caused by cultural differences, which can ensure that the enterprises can react quickly when the external environment changes. Finally, the personnel system should be improved. If the enterprise does not attach importance to the management of talents, a good corporate culture will not play its due role. Therefore, enterprises should establish a perfect personnel system in terms of talent management and incentive system.

\section{B. Respect Cultural Differences}

About 4,000,000,000 people who come from countries and regions with different social systems and religious beliefs are involved by the national implementation of "The Belt and Road" Initiative, who have different cultures and objective cultural differences. In the process of transnational operations, the essence of culture, and the objectivity of the cultural differences must be understood by the enterprises, the cultural differences between China and the countries along the route must be faced, and every culture should be respected for impartially. On the basis of respect for the objectivity of cultural differences, economic and trade cooperation with the surrounding countries and regions is carried out in order to avoid or eliminate the contradictions and conflicts caused by cultural differences [7]. If enterprises can draw support from and make use of cultural differences and give full play to their own advantages, it can not only improve the competitive advantage of enterprises, but also promote the development of enterprises, and then enhance the international competitiveness of enterprises.

\section{CONCLUSION}

Under the impetus of "The Belt and Road Initiative", inevitably, there will be cultural conflicts or crises in the transnational operation of Chinese enterprises. Therefore, it is necessary for enterprises to respond more actively to cultural conflicts or crises, to make a correct understanding of the cultural characteristics of host countries or regions, to make a profound analysis of the causes of cultural differences and their conflicts, and to actively seek ways to effectively avoid and solve cultural conflicts. This will not only prevent cultural conflicts from becoming more and more intense, but also help to resolve cultural conflicts and facilitate convergence and integration among different cultures. As a result, the understanding and cognition of Chinese enterprises and the local people in the host country will be continuously improved, and the brand image and international influence of Chinese enterprises shall be enhanced.

\section{REFERENCE}

[1] Gao Chen, Ma Chengzhi. Cross cultural management in Chinese enterprises "going out" under "The Belt and Road" strategy [J]. China human resources development : 2015, pp. $14 \neg 16$.

[2] Li Shihua. Promoting the cultural integration of Chinese and foreign enterprises under the background of "The Belt and Road" [J]. Enterprise Civilization, 2016, pp. 75-76.

[3] Ma Jingmei. Cross cultural management strategy of multinational corporations [J]. northern Economy and Trade : 2016, pp. 95-96.

[4] Wang Hongying, Bi Yanling. The competitive advantages of transnational corporations from the perspective of cross culture management $[\mathrm{J}]$. Journal of Shandong University of Technology : Social Science Edition : 2016, (3) :44- 47. [5]Wang Guohui. Cross cultural management of transnational corporations [J]. Lanzhou Journal:2015, pp. 40-45.

[5] Zhao Juan. Cross cultural management in Chinese enterprises under "The Belt and Road" strategy [J]. Journal of Beijing Institute of /p"p/;xxcccccf3Graphic Communication : 2017, pp. 70-72.

[6] Wang Guohui. Cross cultural management of transnational corporations [J]. Lanzhou Journal:2015, ppt . 40-45.

[7] Fu Shaoli. Cross cultural management of Chinese transnational corporations [J]. Tianjin Social Sciences : 2014, ppt. 20-24. 